\title{
Potential of Chitosan from Shrimp Waste for Treating Staphylococcus aureus Bacteria in Skin Wound
}

\author{
I Made Satya Widnyana ${ }^{1}$, Sri Subekti $^{{ }^{*}}$, and Kismiyati ${ }^{2}$ \\ ${ }^{I}$ Department of Marine Science, Faculty of Fisheries and Marine, Universitas Airlangga, Surabaya, East Java, Indonesia \\ ${ }^{2}$ Department of Fish Health Management and Aquaculture, Faculty of Fisheries and Marine, Universitas Airlangga, Surabaya, East Java, Indonesia \\ *Corresponding author's Email: ssbendryman@yahoo.com; (iDORCiD: 0000-0003-4816-041X
}

\begin{abstract}
Shrimp or crustacean waste on the skin, head, and feet has not been maximally utilized. Shrimp or crustacean waste can be processed into chitin or chitosan which can provide high added value. Chitosan is one ingredient that can be used to make skin ointments. One of the bacteria that is harmful to the skin during a wound is Staphylococcus aureus. Hence, there is a need to have a skin ointment that can inhibit these bacteria. The current study aimed to evaluate the antibacterial activity of chitosan in the ointment. Moreover, the current study planned to determine the optimum inhibitory concentration of chitosan in the ointment against Staphylococcus aureus and evaluate the physical properties of ointments. The methods used in the current study were the $\mathrm{pH}$ determination, organoleptic test, homogeneity test, and antibacterial activity test to examine chitosan against Staphylococcus aureus. The results showed that chitosan in ointment had a weak antibacterial activity with a value of $<5 \mathrm{~mm}$ inhibition zone. Chitosan with a concentration of $0.2 \%$ in ointment fulfilled the requirements of a good ointment. Its white colour as the typical colour of chitosan showed the characteristic odour of chitosan and a semi-solid form. Chitosan in the ointment has antibacterial activity that can inhibit Staphylococcus aureus bacteria.
\end{abstract}

Keywords: Chitosan, Skin Ointment, Staphylococcus aureus.

\section{INTRODUCTION}

Regarding the antibacterial, antifungal, and antiviral activities of chitosan, it is necessary to develop a product in the pharmaceutical field to benefit from such properties (Chouhan et al., 2017). One of the product preparations in the pharmaceutical field that can facilitate its use is ointment (Ibezim et al., 2018).

Therefore, the current study was conducted to determine the inhibitory concentration of chitosan in ointment against Staphylococcus aureus and evaluate the physical properties of skin ointment preparations.

\section{MATERIALS AND METHODS}

\section{Variables}

The independent variables of the current study included variations in the concentration of chitosan in the ointment. The control variable was chitosan in the ointment, and the heating temperature of chitosan in the ointment was $70^{\circ} \mathrm{C}$, while the dependent variable was inhibition of Staphylococcus aureus and physical phlegm ointment.

\section{Study design}

This study used four treatments in testing the physical properties of ointment preparations, namely $\mathrm{K}$ as the control (commercial ointment), P1 ( $0.05 \%$ chitosan ointment), P2 ( $0.1 \%$ chitosan ointment), and P3 ( $0.2 \%$ chitosan ointment).

\section{Procedures}

The percentage of chitosan concentration in ointments in the current study was based on the study of Chiba et al. (2006) as the amounts of chitosan investigated for topical doses ranged 0.1-5\%. Chitosan at smaller amounts can improve skin wound healing. The analysis of the chitosan-based ointment in the current study started with investigating the physical properties of ointment. In this regard, the $\mathrm{pH}$ test (degree of similarity), organoleptic test, and homogeneity test were conducted. The second phase of the study involved the Staphylococcus aureus inhibitory test according to Yasrebi et al. (2020). 


\section{Statistical analysis}

To analyze the obtained results, one-way ANOVA test was used followed by Duncan in SPSS version 22. The level of significance was set at $\mathrm{p}<0.05$.

\section{RESULTS}

\section{Chitosan pH test in the ointment}

The $\mathrm{pH}$ meter was used to determine the $\mathrm{pH}$ of the chitosan-based ointment. The obtained results indicated that chitosan-based ointments had the lowest and the highest average $\mathrm{pH}$ of 5.87 and 6.15 , respectively. The ideal $\mathrm{pH}$ for the skin ointment was 4.5-6.5. Chitosan with concentrations of $0.05 \%, 0.1 \%$ and $0.2 \%$ in ointments are good for the skin. One-way ANOVA test results on the $\mathrm{pH}$ test of chitosan in the ointment showed that there were significant differences in $\mathrm{pH}$ values between various treatments $(\mathrm{p}<0.05)$. The $\mathrm{pH}$ test of chitosan in ointment had a significant effect on microbial inhibition in the current study $(\mathrm{p}<0.05)$.

\section{Inhibitory tests}

One-way ANOVA test results on the $\mathrm{pH}$ test of chitosan in the ointment showed that there were significant differences in $\mathrm{pH}$ values between various treatments $(\mathrm{p}<0.05)$. The $\mathrm{pH}$ test of chitosan in ointment had a significant effect on microbial inhibition in the current study. The inhibitory test of chitosan bacteria in ointment was conducted to determine the ability of ointments to inhibit the growth of Staphylococcus aureus bacteria and to determine an effective and efficient treatment system. Observations of bacterial inhibition tests were conducted by calculating the diameter of the clear zone and the diameter of What-mann paper. Antibacterial commercial ointment inhibitory zone activity had an inhibition zone of $3.4 \mathrm{~mm}$, ointment with chitosan concentrations of $0.05 \%, 0.1 \%$, and $0.2 \%$ had an inhibition zone of $1.3 \mathrm{~mm}, 1.6 \mathrm{~mm}$, and $4 \mathrm{~mm}$, respectively. The commercial ointment and chitosan-based in ointments had weak antibacterial activity with a value of $5 \mathrm{~mm}$. The inhibition of bacteria as $<5$ indicates the weak, $5-10 \mathrm{~mm}$ shows moderate, 11-20 reveals strong, and $>20$ signifies the very strong activity. One way-ANOVA test results on the antibacterial activity of chitosan in the ointment showed no significant difference among the treatments in terms of their bacterial inhibition zone ( $p>0.05)$.

In the current study, the inhibitory test of chitosan bacteria in ointment did not significantly influence the inhibition zone of the bacteria. There was a weak category of antibacterial activity in chitosan of the ointment with a value of $\leq 5$ $\mathrm{mm}$. Chitosan in ointment with a concentration of $0.2 \%$ has an inhibition zone diameter that was greater than the control treatment which only consists of an ointment base. This was because chitosan has antibacterial properties that can kill bacteria. The greater the concentration of chitosan in the ointment, the greater the inhibitory zone formed.

\section{Homogeneity test}

The observations made on the homogeneity of the ointment base and chitosan in the ointment showed homogeneous, identical, and no coarse particles in the ointment. The chitosan homogeneity test results in ointments of $0.05 \%, 0.1 \%$, and $0.2 \%$ have the same physical properties.

\section{Organoleptic test}

In organoleptic testing, the colour, shape, and odour of the commercial ointment and chitosan-based ointment were evaluated. The first was the test of colour which evaluated the base of the ointment and the chitosan in the ointment in terms of colour. The colour was a yellowish white colour for chitosan-based ointment concentrations of $0.05 \%$ and $0.1 \%$ as well as the commercial ointment. However, $0.2 \%$ of chitosan in the ointment led to the formation of white colour. The Organoleptic Test for odour was used to observe the commercial ointment and chitosan in the ointment regarding aroma. The obtained results indicated that commercial ointment had a distinctive odour of the ointment. While the observation of ointment with $0.05 \%$ chitosan indicated a distinctive odour of ointment, $0.1 \%$ and $0.2 \%$ concentration of chitosan in the ointment led to a distinctive odour of shrimp. The Organoleptic Test of shape was employed for chitosan with concentrations of $0.05 \%, 0.1 \%$, and $0.2 \%$ in ointments in terms of shape and physical form. Kruskal Wallis test results of organoleptic tests on colour, odour, and shape revealed significant differences among the treatments $(\mathrm{p}<0.05)$.

\section{DISCUSSION}

The results obtained at the concentration of $0.2 \%$ chitosan in ointment had the largest inhibitory zone diameter, compared to the control treatment (ointment base), chitosan concentration of $0.05 \%$ in the ointment, and chitosan concentration of $0.1 \%$ in the ointment. It can be stated that the greater the diameter of the inhibition zone formed or the higher the concentration of chitosan in the ointment, the greater is effect on inhibiting the growth of Staphylococcus aureus. 
The PH testing in the current study was very important because it is in direct contact with the skin thus it would affect the condition of the skin (Schmid-Wendtner and Korting, 2006). The ointment pH test was conducted to determine the acidity and basicity of the ointment preparation to the skin. A good $\mathrm{pH}$ value of ointment is $4.5,-6.5$ or by the $\mathrm{pH}$ value of human skin (Lamberts et al., 2006).

The smaller the $\mathrm{pH}$ or the more acidic the preparation, the easier it is to irritate the skin while the higher the $\mathrm{pH}$ value can make the skin dry, therefore, $\mathrm{pH}$ testing was very important in making topical preparations thus preparations made do not irritate the skin when used (Lamberts et al., 2006). The chitosan with concentrations of $0.05 \%, 0.1 \%$, and $0.2 \%$ in ointment did not irritate if applied to the skin so it is a good ointment requirement. One-way-ANOVA test results on the chitosan $\mathrm{pH}$ test in ointments showed that there were significant differences between various treatments ( $\mathrm{p}$ $<0.05)$. The PH test of chitosan in ointment had a significant effect in this study.

Homogeneity testing in the current study was conducted to find out if the ointment preparations was evenly mixed. The homogeneous ointment was characterized by the absence of lumps in the basting result until the end of basting (Barkah, 2016). Homogeneity test results performed on each ointment proved homogeneity if there were no clumping particles and had the same colour on all parts of the ointment. The homogeneity of the ointment can also affect the dose of the ointment when it was used, a homogeneous ointment will give an even dose (Carneiro and Poppi, 2012).

Homogeneous ointment preparations would provide good results because the medicinal ingredients are evenly dispersed in the basic ingredients, hence in each part, the preparations contain the same amount of medicinal ingredients (Abuyeva et al., 2018). If the ingredients of the drug were not dispersed evenly in the basic ingredients, then the drug will not achieve the desired therapeutic effect (Abuyeva et al., 2018). The observations made on the homogeneity of the ointment base and chitosan in the ointment showed homogeneity, evenness, no coarse grains, and lumps in the ointment. The chitosan homogeneity test results in ointments (concentrations of $0.05 \%, 0.1 \%$, and $0.2 \%$ ) have the same physical properties meaning that homogeneity was observed in various treatments and each repetition.

Organoleptic testing in the current study was conducted by observing the ointment preparations from the shape, odour, and colour of the preparations (Barkah, 2016). In organoleptic testing, the colour, shape, and odour of the commercial ointment and chitosan-based ointment were with concentrations of $0.05 \%, 0.1 \%$, and $0.2 \%$ were compared. Observation of the commercial ointment and chitosan-based ointment showed the colour difference of each concentration. The colour formed was yellowish-white in the observation of the ointment base, this is due to the mixing of the white Vaseline albumins and the lanae adeps and cera alba which were yellow which is the typical colour of the mixture of the two ointment bases.

Observation of chitosan in ointment concentration of $0.05 \%$ colour that was formed was yellowish-white colour, chitosan in ointment concentration of $0.1 \%$ colour formed was yellowish-white colour, and chitosan in ointment concentration of $0.2 \%$ colour that was formed was white. This was because the more the concentration of the solution based on the ointment, the colour of the ointment will be more similar to the colour characteristics of the solution used using white chitosan shrimp in this study. Chitosan in ointment concentration of $0.2 \%$ was the best ointment due to the organoleptic test results, the colour formed was white which was the typical colour of chitosan (shrimp). The colour of a good ointment was the distinctive colour or carrier of the ointment preparation (El-Gied et al., 2015).

Observation of the ointment base and chitosan in the ointment regarding odour showed the ointment base has a characteristic ointment odour. This is because the ointment base material used was the ointment produced from oil purification. However, the observation of chitosan in ointment concentration of $0.05 \%$ has a distinctive odour of ointment, chitosan in ointment with the concentration of $0.1 \%$ has a distinctive odour of chitosan (shrimp), and chitosan in the ointment of concentration of $0.2 \%$ has a characteristic odour of chitosan (shrimp). This is because the solution contained mask the odour from the base of the ointment.

Chitosan in ointment concentrations of $0.1 \%$ and $0.2 \%$ was the best ointment because the results of the organoleptic test showed the odour typical of chitosan (shrimp). The higher the concentration of the solution used in the ointment base, the easier it is to find out the characteristic odour used on the ointment. A good odour was the characteristic odour or carrier of the ointment preparation (El-Gied et al., 2015).

Observations on the basis of ointments and chitosan in ointments concentrations of $0.05 \%, 0.1 \%$, and $0.2 \%$ in terms of shape have the same physical form that was semi-solid. The semi-solid form was a characteristic of ointments. Chitosan in ointment concentrations of $0.05 \%, 0.1 \%$, and $0.2 \%$ was the best ointment because organoleptic test results showed the form of semi-solid form. The form of a good ointment preparation has a physical form that was semi-solid (Bharat et al., 2011).

\section{CONCLUSION}

Chitosan in ointment material with a concentration of $0.2 \%$ fulfilled the requirements of a good ointment. The white colour which was the typical colour of chitosan showed the characteristic odour of chitosan and a semi-solid form. Chitosan in ointment had an antibacterial activity that could inhibit Staphylococcus aureus bacteria. 


\section{DECLARATIONS}

\section{Competing interests}

Authors declare no competing interests.

\section{Authors' contribution}

The authors have participated in this study equally.

\section{Ethical consideration}

Ethical issues (Including plagiarism, consent to publish, misconduct, data fabrication and/or falsification, double publication and/or submission, and redundancy) have been checked by the authors.

\section{REFERENCES}

Abuyeva B, Burkitbayev M, Mun G, Uralbekov B, Vorobyeva N, Zharlykasimova D, and Urakaev F (2018). Preparation of ointment materials based on sulfur nanoparticles in water-soluble polymers. Materials Today: Proceedings, 5(11): 22894-22899. DOI: https://doi.org/10.1016/j.matpr.2018.07.107

Barkah MF (2016). Formulasi dan Evaluasi Salep Ekstrak Etanol 70\% Daun Kemangi (Ocimum sanctum L.) Dengan Kombinasi basis PEG 400 DAN PEG 4000. Undergraduate Thesis, Ciamis: Sekolah Tinggi Ilmu Kesehatan Muhammadiyah, Indonesia. Available at: https://adoc.pub/formulasi-dan-evaluasi-salep-ekstrak-etanol-70-daun-kemangi-.html

Bharat P, Paresh M, Sharma RK, Tekade BW, Thakre VM, and Patil VR (2011). A Review: Novel Advances in Semisolid Dosage Forms \& Patented Technology in Semisolid Dosage Forms. International Journal of PharmTech Research, 3 (1): $420-430$. Available at: https://www.sphinxsai.com/Vol.3No.1/pharm_jan-mar11/pdf/JM11(PT=71)\%20pp\%20420-430.pdf

Carneiro RL, and Poppi RJ (2012). Homogeneity study of ointment dosage forms by infrared imaging spectroscopy. Journal of pharmaceutical and biomedical analysis, 58: 42-48. DOI: https://doi.org/10.1016/j.jpba.2011.09.031

Chiba Y, Kamada A, Sugashima S, Kahoru TAYA, Matsubuchi S, Saito T, and Hamada S (2006). Effects of intravenous administration of chitosan origosaccharide on the wound healing process of oral mucosal injury in mice. Ohu University Dental Journal, 33: 27-33. Available at:https://ci.nii.ac.jp/naid/10029055494/

Chouhan S, Sharma K, and Guleria S (2017). Antimicrobial activity of some essential oils-present status and future perspectives. Medicines, 4(3): 58. DOI: https://doi.org/10.3390/medicines4030058

El-Gied AA, Abdelkareem M Abdelkareem, and Elnazeer I Hamedelniel. (2015). Investigation of cream and ointment on antimicrobial activity of Mangifera indica extract. Journal of Advanced Pharmaceutical Technology \& Research, 6(2): 53-57. DOI: https://dx.doi.org/10.4103\%2F2231-4040.154530

Ibezim EC, Momoh MA, Onyishi VI, Nwabunike I, Ibezim NE, and Nzekwe NJ (2018). Wound healing properties of ointment formulations of Ocimum gratissimum crude n-hexane bark extracts using the excision wound model. Journal of Pharmaceutical and Allied Sciences, 15(1): 23-73. Available at: https://www.ajol.info/index.php/jophas/article/view/168619

Lamberts H, S Pliessens, Bloem A, Pronk H, and P Pinkel (2006). Natural skin surface pH is on average Below 5, which is beneficial for its resident flora. International Journal of Cosmetics Science, 28(5): 359-370. DOI: https://doi.org/10.1111/j.14672494.2006.00344.x

Schmid-Wendtner MH, and Korting HC (2006). The pH of the Skin Surface and Its Impact on the Barrier Function. Skin Pharmacology and Physiology, 19(6): 296-302. Available at: https://www.karger.com/Article/Abstract/94670

Yasrebi N, Hatamian Zarmi AS, and Larypoor M (2020). Optimization of Chitosan Production from Iranian Medicinal Fungus Trametes-Versicolor by Taguchi Method and Evaluation of Antibacterial Properties. Iranian Journal of Medical Microbiology, 14(3): 186-200. DOI: http://dx.doi.org/10.30699/ijmm.14.3.186 